\title{
Study of Salted Octopus Drying Kinetics and Hygroscopy from Artisanal Fishing in Agadir Region
}

\author{
Mounia Lekrati* and Zeinebou Hamma Vezaz \\ Department of Fisheries Technologies, Higher Institute of Marine Fisheries, Agadir, Morocco. \\ http://dx.doi.org/10.13005/bbra/2946
}

(Received: 09 August 2021; accepted: 23 October 2021)

\begin{abstract}
Salt-and-dry technique is an artisanal fish conservation method adopted in the Maghreb countries which is based on lowering the water activity. This latter factor is crucial in food preservation, where the relationship between the water activity and the water content of the salted octopus helps control its storage. However, the realization of this processing in controlled conditions is limited by the lack of information regarding the drying time and the behavior towards humidity of this specie. This work describes the drying kinetics by plotting the drying curve $\left(70^{\circ} \mathrm{C} ; 1.5 \mathrm{~m} / \mathrm{s}\right)$ and helps define the salted octopus drying time. Also it presents the desorption and adsorption isotherms at three temperatures which represent the storage temperatures $\left(30,40\right.$ and $\left.50^{\circ} \mathrm{C}\right)$ following the gravimetric method. The drying of the salted octopus carried out helped reduce the water activity to a value of 0.63 and the water content of $0.505 \mathrm{~g}$ water/g MS during 10 hours. In addition, the sorption curves were experimentally determined and modeled by polynomial regression of order 4 . The fitting has given correlation coefficients close to 1 for the three temperatures.
\end{abstract}

Keywords: Adsorption; Desorption; Drying kinetics; Mathematical Adjustment; Octopus Vulgaris, Sorption isotherms.

Used in the Maghreb culinary traditions and especially Moroccan (in couscous and with legumes), commun octopus (Octopus vulgaris) is a very exploited specie in Morocco, where we find, on one hand, the catch of the deep-sea octopus fishery estimated at 14,637 tons in 2019 , and on the other hand, the volume of cephalopods and particularly commun octopus, marketed by the coastal and artisanal fishing fleet reached in weight 48299 tons for the same year ${ }^{1}$.
According to the latest report from the Food and Agriculture Organization of the United Nations (FAO) ${ }^{2}$, Morocco and China were the largest octopus exporters during 2016 and 2017.

Furthermore, Octopus, like the other Cephalopods, is filled with healthy nutrients like proteins, omega-3 fatty acids and a number of micronutrients, making it an evident future food resource $^{3-4}$. 
In order to conserve this resource, several types of industrial valorization are adopted in Morocco, in particular, freezing 5 , whereas the drying preceded by salting constitutes a process of artisanal valorization which makes it possible to conserve the octopus by reducing its water activity (aw) while improving its organoleptic quality. This artisanal method takes place in nonmastered conditions, and the humidity sorption of salted octopus remains unknown. That is why it is important to study the salted octopus drying in controlled conditions, to determine its drying time and to define its behavior towards air humidity.

So, this work aims to study the controlled drying of salted octopus by determining the drying kinetics of salted octopus carried out under the optimal conditions of this process ${ }^{6}$ in order to determine the drying time and the water presence variation in the product before and after the drying. And also experimentally determine the sorption isotherms of salted octopus for air temperatures between $30^{\circ} \mathrm{C}$ and $50^{\circ} \mathrm{C}$. These curves make it possible to determine the evolution of aw as a function of the modification of the water content (hydration, dehydration) to prevent degradation phenomena during octopus storage as well as the final water content of a product to be dried ${ }^{7}$. The typical shape of an isotherm reflects how water is related to the product ${ }^{8}$. Thus, the sorption isotherm is an extremely valuable tool for characterizing salted octopus, for determining optimal storage conditions, for choosing packaging and for determining shelf life during storage ${ }^{9}$.

This curve also helps predicting, on the one side, the physicochemical transformations (non-enzymatic reactions, browning and oxidation of lipids) which may take place in the product, and on the other, the transformations that are the result of microbial growth and enzymatic reactions. All of these processes determine the degradation mechanism that is directly related to the water activity in food products ${ }^{10}$.

The most widely used experimental method of obtaining the sorption equilibrium data of meat is a static method using a gravimeter method $^{11}$. In this method, the sample is exposed to atmospheres of known relative humidity that are controlled with different salts.

The obtained experimental adsorption and desorption curves are adjusted by polynomial regression for all the studied temperatures.

Table 1. Relative humidities of saturated salt solutions

\begin{tabular}{lccccc}
\hline Temperature & $\mathrm{MgCl}_{2}, 6 \mathrm{H}_{2} \mathrm{O}$ & $\mathrm{K}_{2} \mathrm{CO}_{3}$ & $\mathrm{NaNO}_{3}$ & $\mathrm{KCl}$ & $\mathrm{BaCl}_{2}, 2 \mathrm{H}_{2} 0$ \\
\hline $30^{\circ} \mathrm{C}$ & 0,3238 & 0,4317 & 0,7275 & 0,8362 & 0,8980 \\
$40^{\circ} \mathrm{C}$ & 0,3159 & 0,4230 & 0,7100 & 0,8232 & 0,8910 \\
$50^{\circ} \mathrm{C}$ & 0,3054 & 0,4091 & 0,6904 & 0,8120 & 0,8823 \\
\hline
\end{tabular}
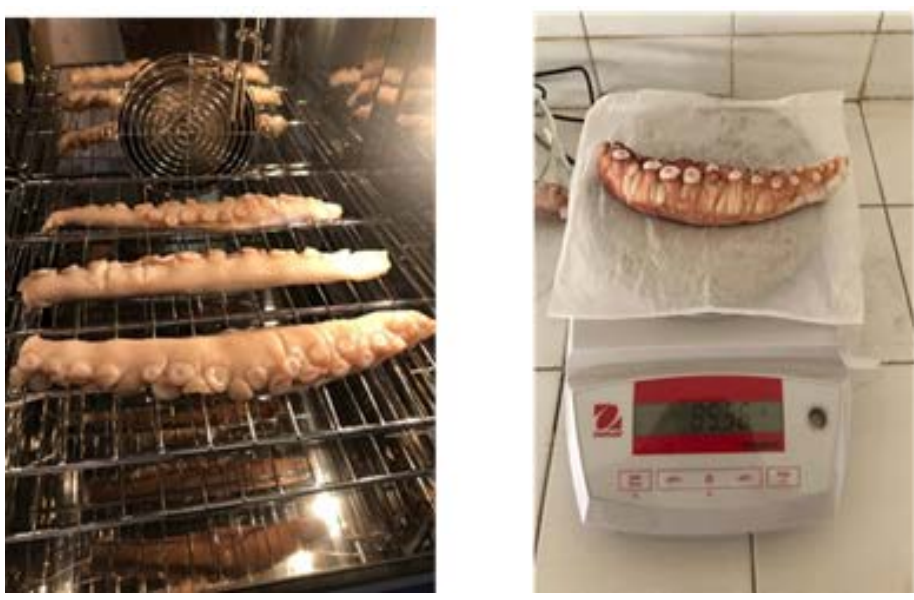

Fig. 1. Salted octopus drying

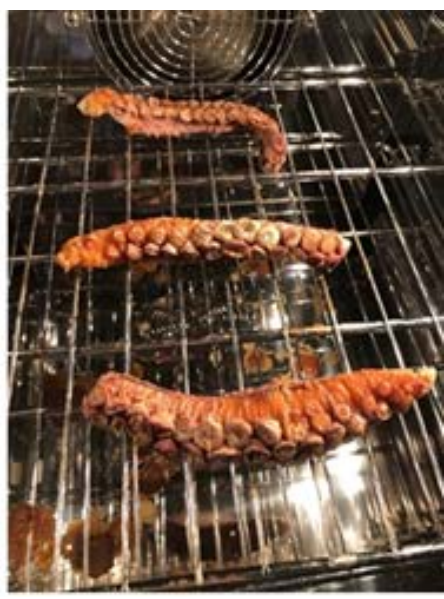




\section{MATERIALS AND METHODS}

\section{Sampling}

The studied specie is Octopus vulgaris. The sample was fished by the artisanal fishing technique in the artisanal segment of Agadir where it is authorized to operate in the band from 3 to 8 miles at the management unit.

\section{Preparation of salted octopus}

The samples were eviscerated and washed and then threshed in order to break up the fibers and speed up the drying process. The mass yield of these operations is $80 \%$. The octopus was subsequently subjected to a dry salting of $30 \%$ for 2 hours to reduce its water content and improve its organoleptic quality.

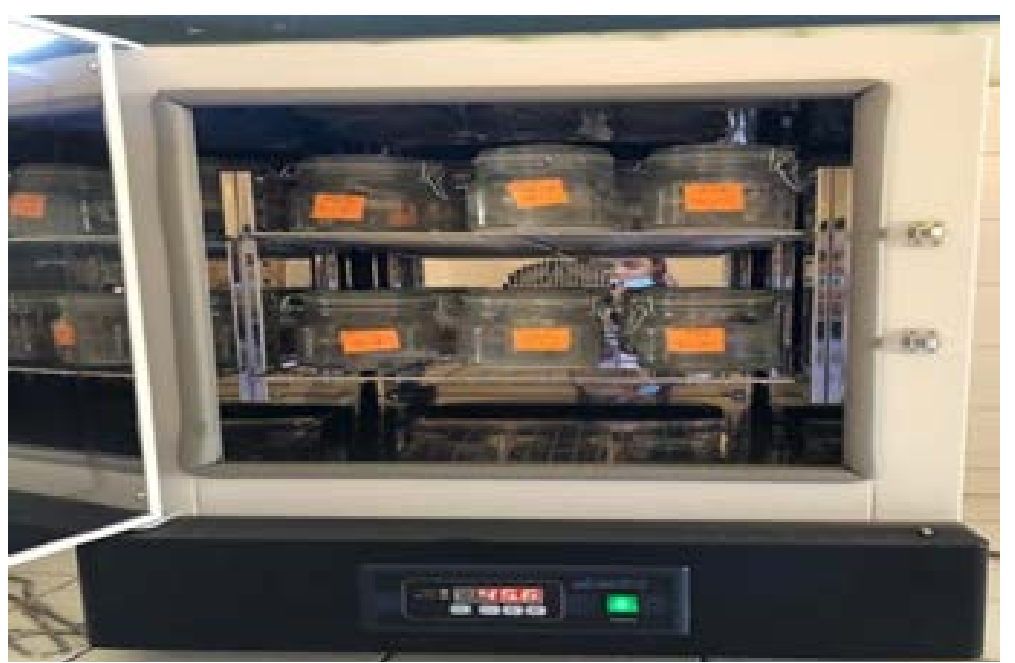

Fig. 2. Octopus samples maintained at constant temperature and relative humidity

Salted octopus drying curve at $70^{\circ} \mathrm{C}$ and $1,5 \mathrm{~m} / \mathrm{s}$

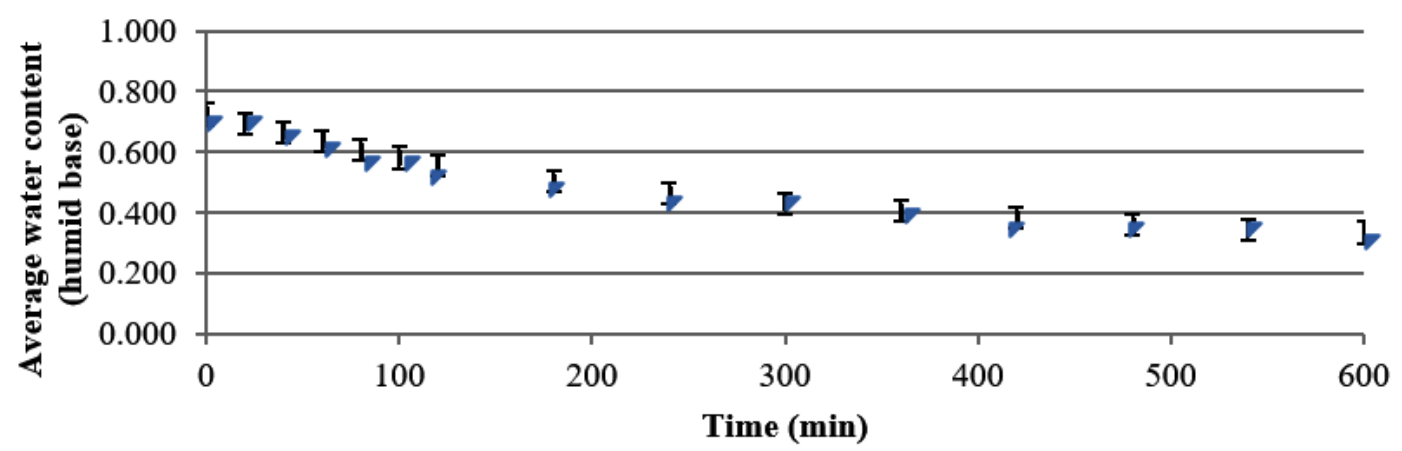

Fig. 3. Salted octopus drying curve at $70^{\circ} \mathrm{C}$ and $1,5 \mathrm{~m} / \mathrm{s}$

Table 2. Water presence in the salted octopus before and after the salt-and-dry processes

\begin{tabular}{lcccc}
\hline $\begin{array}{l}\text { Salted } \\
\text { octopus }\end{array}$ & $\begin{array}{c}\text { Water content } \\
\text { (dry base) }\end{array}$ & $\begin{array}{c}\text { Humidity \% } \\
\text { (humid base) }\end{array}$ & aw & Temperature \\
\hline Before salting & 4,379 & 80,3 & 0,934 & $24{ }^{\circ} \mathrm{C}$ \\
Before drying & 2,232 & 69,0 & 0,884 & $24{ }^{\circ} \mathrm{C}$ \\
After drying & 0,505 & 33,5 & 0,630 & $24{ }^{\circ} \mathrm{C}$ \\
\hline
\end{tabular}


After draining for 30 minutes, the final mass yield of all the pretreatment operations carried out is $72.45 \%$. Three $30 \mathrm{~cm}$ long and $2 \mathrm{~cm}$ thick samples were cut from the upper parts of the octopus tentacles.

\section{Water analysis of octopus}

Water activity of an octopus sample was measured before and after both salting and drying operations by a Portable Water Activity Analyzer (Hygropalm - HP23-AW-A model). Also, each sample is placed in an oven regulated at $105^{\circ} \mathrm{C}$ for 24 hours in order to measure its dry mass for determining its water content.

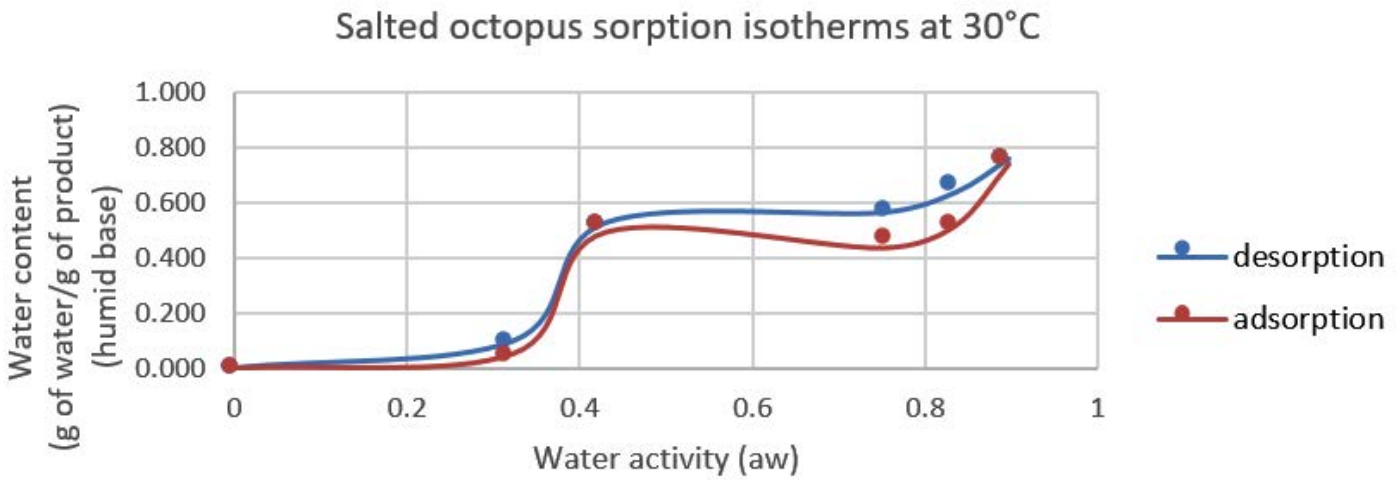

Fig. 4. Salted octopus sorption isotherms at $30^{\circ} \mathrm{C}$

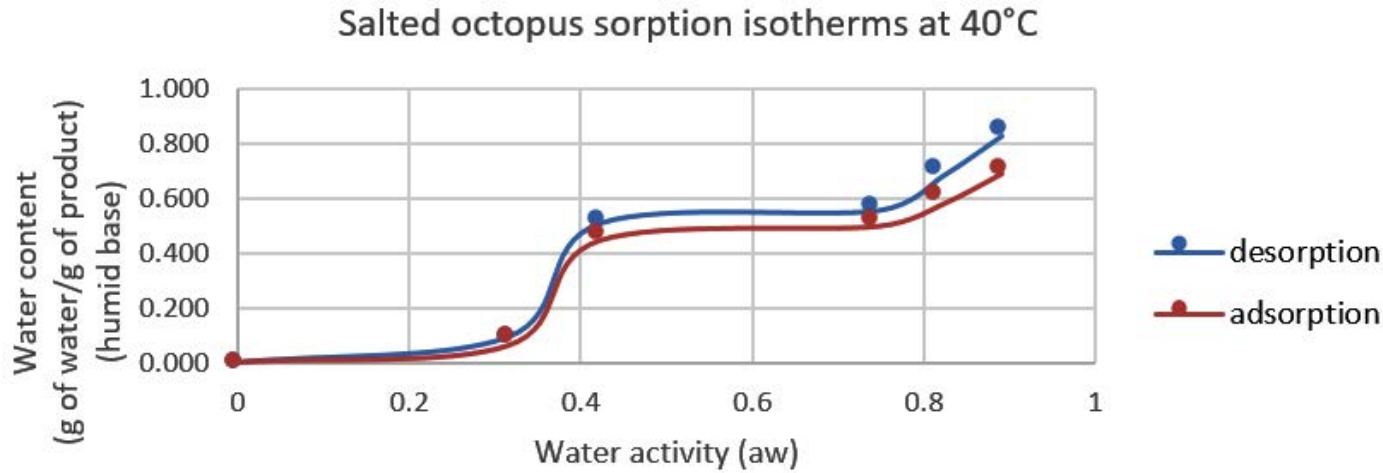

Fig. 5. Salted octopus sorption isotherms at $40^{\circ} \mathrm{C}$

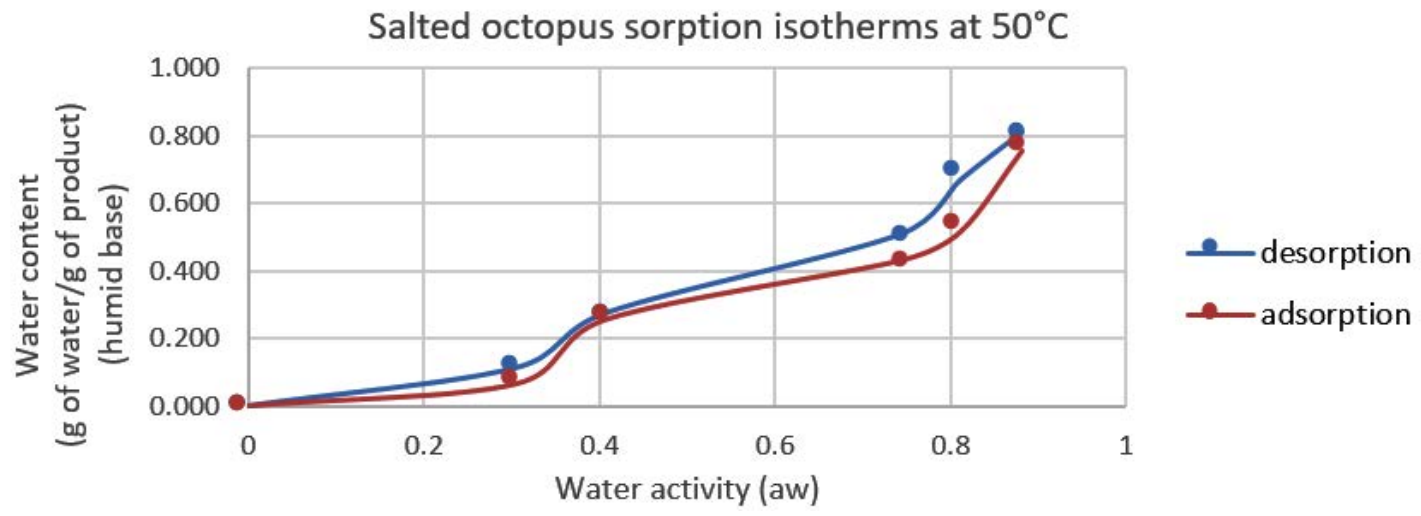

Fig. 6. Salted octopus sorption isotherms at $50^{\circ} \mathrm{C}$ 


\section{Drying of salted octopus}

Three samples of octopus were dried by entrainment in a fan dryer (france Etuves - XU058 model) at a temperature of $70^{\circ} \mathrm{C}$ and an air speed of $1.5 \mathrm{~m} / \mathrm{s}^{6}$. The mass loss of the product during the drying is measured, while measuring the weight every 20 minutes at the start of the drying experiment and then every hour using an electric balance (OHAUS - PX5202/E) with a precision of 0.01 (Figure 1 ).
Determination of salted octopus sorption isotherms

Preparation of saturated salts solutions

The used saturated salt solutions (LobaChemie) are prepared in airtight jars and are kept isothermal in 3 ovens set at 3 different temperatures $\left(30^{\circ}, 40^{\circ} \text { and } 50\right)^{12-13}$. Table 1 shows the relative humidities corresponding to the saturated salt solutions at the different adopted temperatures.

\section{Salted octopus adsorption isotherms}

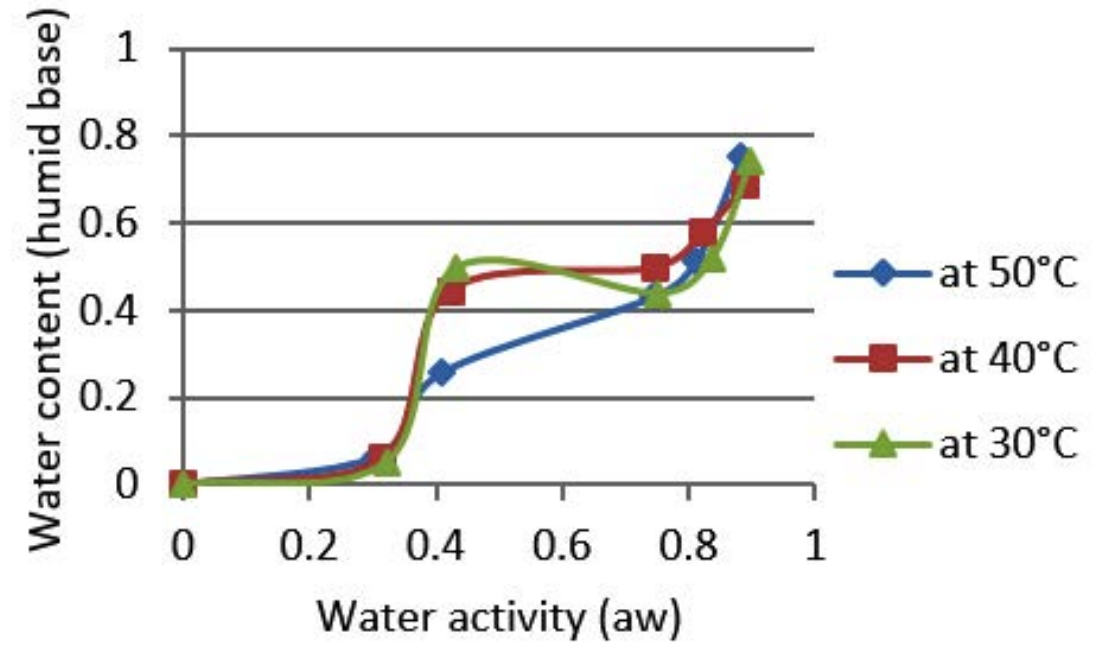

Fig. 7. Adsorption isotherms of salted octopus at different temperatures

\section{Salted octopus desorption isohterms}

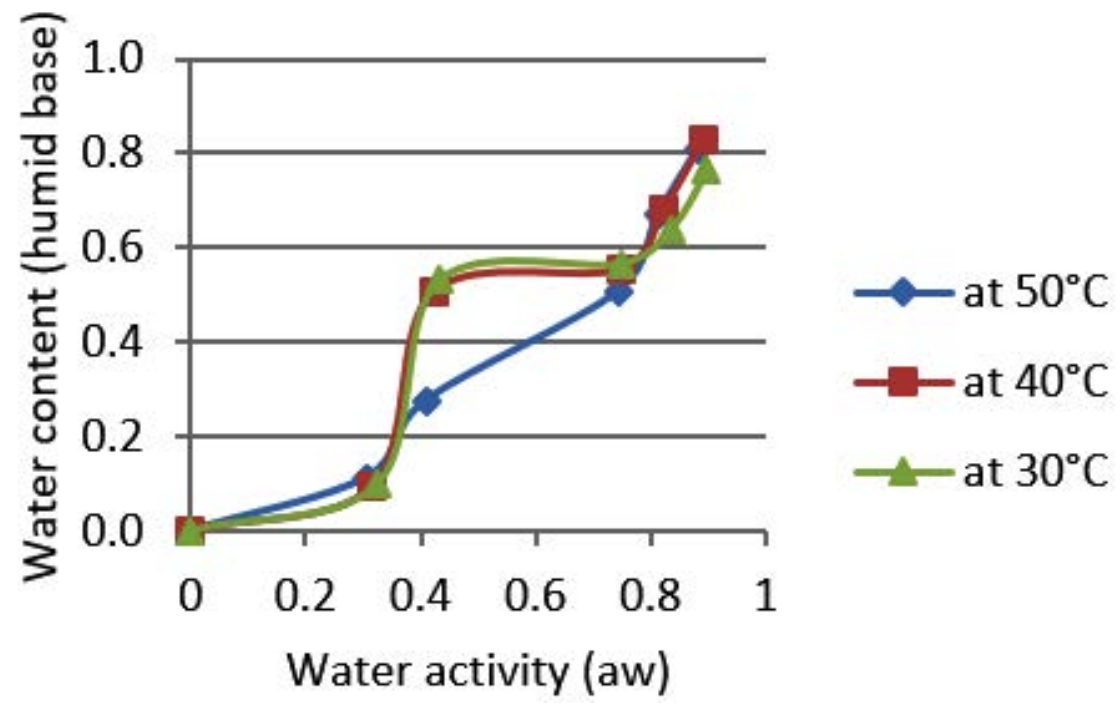

Fig. 8. Desorption isotherms of salted octopus at different temperatures 


\section{Experimental determination method of sorption isotherms}

Octopus samples were dried in order to study the adsorption isotherm and other humid ones for the desorption study. Each sample weighing $2,000 \pm 0.001 \mathrm{~g}$ is hung in the jar, above the saline solution, and therefore remains in a stabilized environment in temperature and hygroscopy (figure 2). Sample weighing was regularly done, until the measured weight becomes stable, this means that the hygroscopic equilibrium is reached.

As soon as the equilibrium masses are determined, the samples are placed in an oven to measure their dry masses for calculating their water content at equilibrium ${ }^{14}$. The required time to obtain the equilibrium varied between 30 and 40 days.

\section{Sorption mathematical modeling}

To mathematically fit the experimentally determined octopus sorption curves, the data (aw, water content) was correlated by polynomial regression (software CurveExpert). The correlation coefficient $\left(\mathrm{r}^{2}\right)$ was used to evaluate the adopted model, where we obtain a good fit when it is close to 1 .

\section{RESULTS AND DISCUSSIONS}

\section{Determination of the drying curve of salted octopus}

The curve in figure 3 represents the evolution of the average water content from the drying of 3 salted octopus samples (in $g$ of water/ $\mathrm{g}$ of salt octopus) as a function of time (in $\mathrm{min}$ ) under optimal drying conditions $\left(70^{\circ} \mathrm{C} ; 1.5 \mathrm{~m} / \mathrm{s}\right)$.

The effect of salting and drying on the water content and water activity of the octopus is shown in Table 2:

\section{Experimental determination of salted octopus sorption isotherms}

Hygroscopic equilibrium is reached for the octopus after 40 days. The hysteresis phenomenon is observed for the sorption isotherms at the different adopted temperatures (30, 40 and 50 ${ }^{\circ} \mathrm{C}$ ) as shown in figures 4, 5 and 6 . These curves show that for a constant relative humidity, the water content of desorption is higher than that of adsorption. They also show that sorption isotherms have a sigmoidal shape, similar to those commonly presented by products.

The obtained experimental curves show that for the same relative humidity, the equilibrium water content increases when the temperature decreases, which is in agreement with other results presented in the literature ${ }^{14-16}$

From Figures 8 and 9, the results show the temperature dependence and the sorption process.

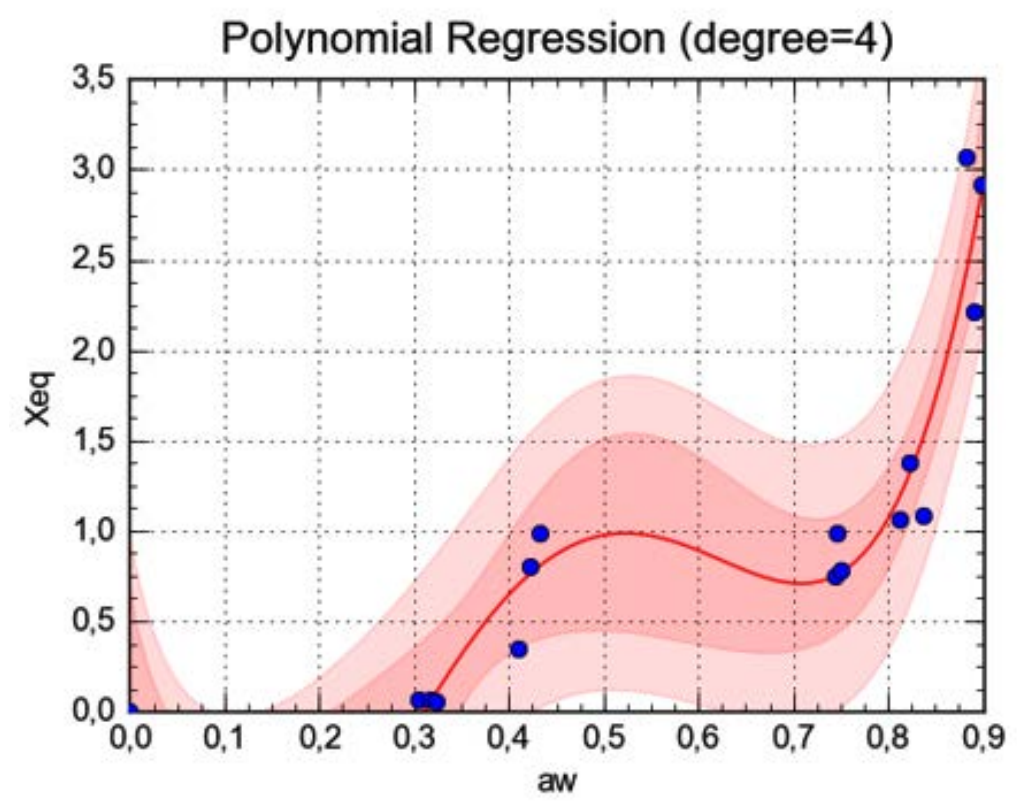

Fig. 9. Adjustment of adsorption experimental points of dried salted octopus by polynomial regression 


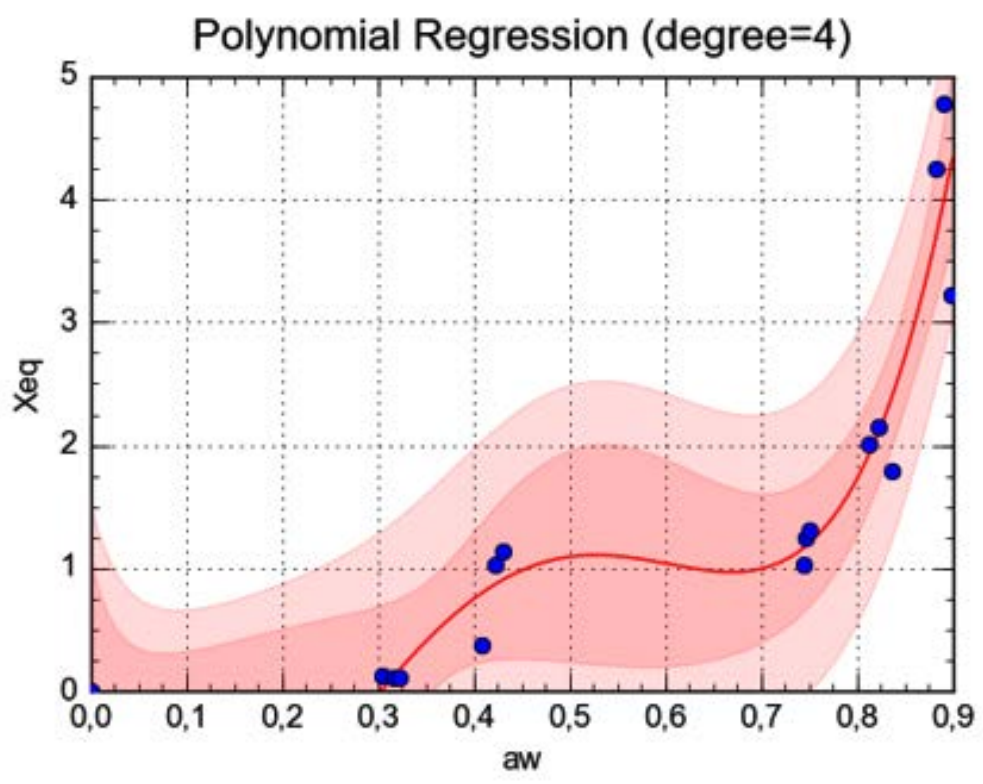

Fig. 10. Desorption experimental points adjustment of salted octopus by polynomial regression

Thus, an increase in temperature has the effect of decreasing the sorption capacity. Under the effect of temperature, water molecules are activated under the effect of thermal agitation, which weakens their adsorption relation and therefore reduces the water content of the product.

Sorption isotherms modeling of salted octopus Several used models for sorption curves adjusting in the food industry ${ }^{17-23}$ and in particular for meat and fishery products ${ }^{15,24-26}$, were tested but they did not show a good fit. However, polynomial regression gave better precision for all the studied temperatures.

Figures 10 and 11 show that the 4th degree polynomial fit gave a good correlation especially for the water activity interval of [0.3-0.9] for the absorption curves as well as the desorption curves.

The equation which relates the equilibrium water content (dry base) with the water activity upon absorption is (Standard Error $=0.307$; Correlation Coefficient $=96.1 \%) \quad$ :

$X e q=0.005-23.728 a_{w}+137.799 a_{w}{ }^{2}-239.300$ $\mathrm{a}_{\mathrm{w}}^{3}+132.741 \mathrm{a}_{\mathrm{w}}^{4}$

The equation which relates the equilibrium water content (dry mass base) with the water activity in the case of desorption is (Standard Error $=0.497$; Correlation Coefficient $=95.7 \%$ ):
Xeq $=0.001-25.120 a_{w}+148.955 a_{w}{ }^{2}-263.911$ $\mathrm{a}_{\mathrm{w}}^{3}+150.391 \mathrm{a}_{\mathrm{w}}^{4}$

\section{CONCLUSION}

Entrainment drying of the salted octopus that was carried out in optimal conditions (at a temperature of $70^{\circ} \mathrm{C}$ and an air speed of $1.5 \mathrm{~m} / \mathrm{s}$ ) lasted for 10 hours. This drying, preceded by $30 \%$ salting for 2 hours, stabilized the product and produced dried salted octopus with water content (humid base) of $33.5 \%$ and water activity of 0.63 .

The desorption and adsorption isotherms of salted octopus were determined experimentally at 30,40 and $50^{\circ} \mathrm{C}$ (possible storage temperatures) by the saturated salt method to describe how water activity of this product changes with its water content in storage conditions. The experimental results show that the sorption isotherms admit a good polynomial regression of degree 4 with correlation coefficients greater than $95 \%$.

\section{ACKNOWLEDGEMENT}

Authors of this work express their sincere thanks to all those who participated in the realization of this present article; especially Khalid 
Lhichou professor of Food Quality in the Higher Institute of Marine Fisheries.

\section{Conflict of Interest}

All authors are requested to disclose any conflict of interest including honorarium, grants, membership, employment, ownership of stock or any other interest or non financial interest such as personal or professional relation, affiliation and knowledge of the research topic.

\section{Funding Source}

This study was funded by the higher Institute of Marine Fisheries.

\section{REFERENCES}

1. Ministère de l'Agriculture, de la Pêche Maritime, du Développement Rural et des Eaux et Forêts Département de la Pêche Maritime, Royaume du Maroc. La mer en chiffres 2019. 2019; pp 6.

2. FAO. La situation mondiale des pêches et de l'aquaculture - atteindre les objectifs de développement durable. 2018 ; pp 76.

3. Mouritsen Ole G., Styrbæk K.. Cephalopod Gastronomy - A Promise for the Future. Frontiers in Communication, 2018; 3 DOI: 10.3389/ fcomm.2018.00038

4. Food and Agriculture Organization of the United Nations. The State of World Fisheries and Aquaculture 2018 - Meeting the Sustainable Development Goals. FAO: Rome, Italy, 2018. Available online: http://www.fao.org/3/i9540en/ i9540en.pdf

5. Ministère de l'Agriculture, de la Pêche Maritime, du Développement Rural et des Eaux et Forêts Département de la Pêche Maritime, Royaume du Maroc. Rapport d'activité 2018. 2018 ; pp 5.

6. Vega-Gálvez A., Miranda M., Clavería R., Quispe I., Vergara J., Uribe E., Paez H., Di Scala K.. Effect of air temperature on drying kinetics and quality characteristics of osmo-treated jumbo squid (Dosidicus gigas). Food Science and Technology, 2011; 44:16-23,

7. Bizot H., Riou N. et Multon J.-L. Guide pratique pour la détermination des isothermes de sorption et de l'activité de l'eau. Sciences des Aliments. 1987. numéro hors série,

8. Wolf W., Speiss W.E.L. and Jung G. : Standardization of Isotherm Measurements. In: D. Simatos and J.L. Multon (Eds.). Properties of Water in Food, Marins Nijhoff Publ. The Netherlands:1985; pp. $661-679$.

9. Tunç S. and Duman O. Thermodynamic Properties and Moisture Adsorption Isotherms of Cottonseed Protein Isolate and Different
Forms of Cottonseed Samples. Journal of Food Engineering. 2007; 81(1): 133-143.

10. Erbas M., Ertugay M.F. and Certel M. Moisture Adsorption Behaviour of Semonila and Farina. Journal of Food Engineering. 2005; 68: 191198.

11. Wolf W., Spiess W. E. L., and Jung G. Standarization of isotherm measurement (COSTproject 90 and 90 bis). In D. Simatos, \& J. L. Multon (Eds.). Properties of water in foods. Dordrecht, The Netherlands: Martinus Nijhoff Publishers. 1985 ; pp 661"679.

12. Bizot H. et Multon J.L. Méthode de référence pour la mesure de l'activité de l'eau dans les produits alimentaires. Anales de Technologie Agricole. 1978 ; 27: 441.

13. Lamharrar A., Kane C. S. E., Idlimam A., Akkad S., Kouhila M. Détermination expérimentale des isothermes de sorption et de la chaleur isostérique des feuilles d'absinthe et de menthe pouliot. JITH (Journées Internationales de Thermique). 2007; 13: 5 .

14. Hart F. L. and Fisher H. J. Modern food analysis. New York: Springer. 1971 ; pp 519.

15. Lopes Filho J.F., Romanelli P.F., Barboza S.H.R., Gabas A.L., Telis-Romero J. Sorption isotherms of alligator's meat (Caiman crocodilus yacare). Journal of Food Engineering. 2002; 52: 201-206.

16. Tom A., A Waste A., Bruneau D.. Séchage solaire de viande de bœuf. Caractérisation expérimentale du produit, modélisation et mise en place d'un séchoir solaire adapté au pays tropicaux. $21^{\mathrm{ème}}$ Congrès Français de Mécanique, Bordeaux. 2013.

17. Rahmana M. S., Al-Khusaibia M. K., AL-Farsia K. A., Al-Bulushia I. M., Abushelaibib A., and Al-Habsia N. Moisture Sorption Isotherm and Thermal Characteristics of Freeze-Dried Tuna. International Journal of Food Studies. 2019; 8: 87-96.

18. Lúcia Lourenço F.H., Daniela Santos C., Suezilde Ribeiro C.A, HellenAlmeida, Eder Araujo A.F. Study of adsorption isotherm and microbiological quality of fish meal type "piracuí" of Acari-Bodo (Liposarcus pardalis, Castelnau, 1855). Procedia Food Science. 2011; 1: 455-462,

19. Rizvi S. S. H. Thermodynamic properties of foods in dehydration. In Rao M. A. \& Rizvi S. S. H. (Eds.). Engineering properties of foods. New York: Academic Press [Chapter 6]. 1995.

20. Labuza T. P., Lomauro C. J. and Baskshi A. S. Evaluation of food moisture sorption isotherm equations. Part I: Fruit, vegetable and meat products. Lebensmittel-Wissenschaft + Technologie. 1985; 18: 111-117. 
21. Hailwood, A. J. and Horrobin, S. Absorption of water by polymers: Analysis in terms of a simple model. Transactions Faraday Society. 1946; 42B: 84-99.

22. Boquet R., Chirife J., \& Iglesias H. A. Equations for fitting water sorption isotherms of foods, II. Evaluation of various twoparameter models. Journal of Food Technology. 1978 ;13: 319-327.

23. Brunauer S., Emmett P. H., and Teller E. (1938). Adsorption of gases in multimolecular layer. Journal of American Chemical Society. 1938; 60: 309-319.
24. Cortés F.B., Farid Chejne F. A rapid and novel approach for predicting water sorption isotherms and isosteric heats of different meat types. Meat Science. 2010; 86: 921-925.

25. Abdenouri N., Idlimam A. et Kouhila M. Etude hygroscopique du lait en poudre. Revue des Energies Renouvelables SMSTS'08. 2008:35 44.

26. Labuza T.P., Kaanane A. and Chen J.Y., Effect of Temperature on the Moisture Sorption Isotherms and Water Activity Shift of Two Dehydrated Foods. Journal of Food Science. 1985; 50(2): 385-392. 